23

\section{A Short History of Irish Memory in the Long Twentieth Century}

GUY BEINER

On the cusp of the twentieth century, Ireland was obsessed with memorialisation. This condition reflected a transnational zeitgeist that was indicative of a crisis of memory throughout Europe. The outcome of rapid modernisation, manifested through changes ushered in by such far-reaching processes as industrialisation, urbanisation, commercialisation and migration, raised fears that the rituals and customs through which the past had been habitually remembered in the countryside were destined to be swept away. The future of memory was deemed uncertain.

Preoccupation with memory is pervasive in the writing of the period. It is apparent, for example, in the philosophy of Henri Bergson - namely in Matter and Memory [Matière et mémoire (1896)], the psychology of Sigmund Freud (as evident in several of his landmark essays) and, perhaps most famously, in Marcel Proust's classic novel À la récherche du temps perdu (1913-1927), originally translated as Remembrance of Things Past. ${ }^{1}$ Writing in the early-twentieth century, the sociologist Émile Durkheim maintained that group identity requires a sense of continuity with the past. ${ }^{2}$ This embryonic notion of social memory

1 R. Terdiman, Present Past: Modernity and the Memory Crisis (Ithaca and London: Cornell University Press, 1993). See also relevant chapters in S. Radstone and B. Schwarz (eds.), Memory: Histories, Theories, Debates (New York: Fordham University Press, 2010): K. Ansell-Pearson, 'Bergson on Memory', 61-76; R. Terdiman, 'Memory in Freud', 93-108; M. Wood, 'Proust: The Music of Memory', 109-122.

2 É. Durkheim, The Elementary Forms of the Religious Life, translated by J. W. Swain (London: G. Allen \& Unwin, Ltd, 1915). See also W. Gephart, 'Memory and the Sacred: The Cult of Anniversaries and Commemorative Rituals in the Light of The Elementary Forms', in N. J. Allen, W. S. F. Pickering and W. W. Miller (eds.), On Durkheim's Elementary Forms of Religious Life (London and New York: Routledge, 1998), 127-35; B. A. Misztal, 'Durkheim on Collective Memory', Journal of Classical Sociology, 3 , (1 July 2003), 123-43. It is disappointing that a Durkheimian study of Irish national identity falled to pick up on the significance of memory; see J. Dingley, Durkheimand National Identity in Ireland: Applying the Sociology of Knowledge and Religion (New York: Palgrave Macmillan, 2015) would later be developed by his disciple Maurice Halbwachs, who coined the term collective memory ('la mémoire collective'). By calling attention to the social frameworks in which memory is framed ('les cadres sociaux de la mémoire'), Halbwachs presented a sound theoretical model for understanding how individual members of a society collectively remember their past. $^{3}$ The impression that modernisation had uprooted people from tradition and that mass society suffered from atomised impersonality gave birth to a vogue for commemoration, which was seen as a fundamental act of communal solidarity, in that it projected an illusion of continuity with the past. ${ }^{4}$

Ireland, outside of Belfast, did not undergo industrialisation on a scale comparable with England, and yet Irish society was not spared the upheaval of modernity. The Great Famine had decimated vernacular Gaelic culture and resulted in massive emigration. An Irish variant of fin de siècle angst over degeneration fed on apprehensions that British rule would ultimately result in the loss of 'native' identity. The perceived threat to national culture, articulated in Douglas Hyde's manifesto on 'The Necessity for De-Anglicising Ireland' (1892), stimulated a vigorous response in the form of the Irish Revival (see Chapter 8 , this volume by Ó Conchubhair). The flourishing of homegrown literary production was dubbed by William Butler Yeats 'The Celtic Twilight' for its creative engagement with myths from a distant quasi-historical past. In addition, the Gaelic League set out to revive the Irish language and the Gaelic Athletic Association (GAA) reinvented traditional sportive games. By participating in popular commemorative rituals, such as the annual parades for the Manchester Martyrs (three Fenians who had been convicted and executed for killing a policeman during a prisoner rescue operation in England), nationalists of all shades endorsed a Fenian cult of political martyrdom, which was also expressed in the singing of ballads, such as the anthemic 'God Save Ireland'.

3 Written in the interwar period, the seminal writings of Halbwachs were only translated into English at a much later date; see M. Halbwachs, The Collective Memory (New York: Harper \& Row, 1980); M. Halbwachs, On Collective Memory (Chicago and London: University of Chicago Press, 1992).

4 For a sociological discussion of commemorative ceremonies as a 'compensatory strategy' of modernity, see P. Connerton, How Societies Remember (Cambridge University Press, 1989), 41-71.

5 G. Beiner, 'Fenianism and the Martyrdom-Terrorism Nexus in Ireland before Independence', in D. Janes and A. Houen (eds.), Martyrdom and Terrorism: Pre-Modern to Contemporary Perspectives (Oxford University Press, 2014),199-220 (esp. 200-7); O. McGee, " "God Save Ireland": Manchester-Martyr Demonstrations in Dublin, 1867-1916", ÉtreIreland, 36, (2001), 39-66. 
Elsewhere in Europe, civic cults of anniversaries were introduced by modern states through such ceremonies as the inauguration of Bastille Day in the French Third Republic (1880), the commemoration of the Magyar Millennium in Hungary (1896), and the marking of Bismarck's death in Germany (1898). ${ }^{6}$ Similarly, in 1897 the Diamond Jubilee of Queen Victoria was celebrated in Ireland not only by Protestants but also by large numbers of the Catholics, who seemed willing to participate in British imperial memorial culture. ${ }^{7}$ Anxieties over such displays of popular loyalism mobilised nationalists, who in 1898 orchestrated numerous celebrations of the centenary of the 1798 Rebellion in a massive demonstration of counter-hegemonic remembrance. The overwhelming success of the centennial commemorations and the subsequent boom of what has been labelled 'statuomania', in reference to the enthusiasm in which communities throughout Ireland rushed to erect monuments to the United Irishmen, can be attributed above all to the agency of local '98 Clubs. These were typically dominated by school teachers, parish priests, newspaper editors and local politicians, who mediated between the political demands of a metropolitan nationalist leadership based in Dublin and London and the grassroots expectations for recognition of provincial folk memory, facilitating what can be labelled regeneration, or reinvention, of tradition. ${ }^{8}$

As a 16-year-old youth, James Joyce was among the crowd of 100,000 who attended the main centenary event in Dublin on 15 August 1898 and witnessed the ceremonial laying of the foundation stone for an intended monument in honour of the 'father of Irish republicanism', Theobald Wolfe Tone. In A Portrait of the Artist as a Young Man (1916), he irreverently recalled this moment as a 'scene of tawdry tribute'. In 1903, the rituals of nationalist commemoration were reaffirmed in the centenary of the execution of the republican martyr Robert Emmet, which was celebrated in Dublin with yet another massive procession. Joyce, however, would look back at the unfulfilled promise to construct a monument on Stephen's Green ('where Wolfe Tone's statue was not'), which would instead become the site of a memorial arch for the

6 E Hobsbawm, 'Mass-Producing Traditions: Europe, 1870-1914', in E. Hobsbawm and T. Ranger (eds.), The Invention of Tradition (Cambridge University Press, 1983), 263-307.

7 J. H. Murphy, Abject Loyalty: Nationalism and Monarchy in Ireland During the Reign of Queen Victoria (Washington, DC: Catholic University of America Press, 2001). For similar reactions to royal visits in the early-twentieth century see S. Pašeta, 'Nationalist Responses to Two Royal Visits to Ireland, 1900 and 1903', Irish Historical Studies, 31124 (1999), 488-504.

8 G. Beiner, Remembering the Year of the French: Irish Folk History and Social Memory (Madison, WI: University of Wisconsin Press, 2007), 243-75. soldiers of the Royal Dublin Fusiliers who fought in the Boer War. Joyce's compulsion to capture in Ulysses (1922) the minutiae of life on the streets of Dublin at the turn of the century produced a literary monument to a city on the verge of change that embodies the very essence of the modernist crisis of memory. ${ }^{9}$

The young generation that participated in the commemorations of the centenary of the United Irishmen was schooled on veneration of memory. ${ }^{10}$ The graveside oration delivered by Patrick Pearse at the funeral of the veteran Fenian Jeremiah O'Donovan Rossa on 1 August 1915 encapsulated their belief in the regenerative power of remembrance of the dead: 'Life springs from death and from the graves of patriot men and women spring living nations. ${ }^{31}$ Many of the events that took place in the revolutionary decade between 1912 and 1923 were subject to instant mythologising. Above all, 1916 stands out as a cornerstone of twentieth-century Irish memory. Both nationalists and unionists re-adapted familiar motifs from historical traditions that pivoted on themes of trauma and triumph in order to construct evocative memories of blood sacrifice, which were quickly adopted as foundation myths by the ascendant political cultures of twentieth-century Ireland: the Easter Rising for nationalist Independent Ireland, and the Battle of the Somme for Unionist Northern Ireland. ${ }^{12}$

Revolutions characteristically entail the replacement of commemorative iconography associated with the previous regime. Moreover, partitions localise and intensify conflicts over the symbols of national memory. A contemporary comparison can be found in Central Europe by considering the partition of the Austro-Hungarian empire, following the Trianon Peace Treaty (1920). In a resentful reaction to the condescending policies of Magyarisation, Hungarian monuments were defaced and replaced with local nationalist memorials in the newly established states of Czechoslovakia and the Kingdom of Serbs, Croats and Slovenes, as well as in the province

9 L Gibbons, "Where Wolfe Tone's Statue Was Not". Joyce Monuments and Memory", in I. McBride (ed.), History and Memory in Modern Ireland (Cambridge University Press, 2001), 139-59. For essays on the many aspects of memory that appear in the works of Joyce, see O. Frawley and K. O'Callaghan (eds.), Memory Ireland, vol. 4: James Joyce and Cultural Memory (Syracuse: Syracuse University Press, 2014).

10 R. F. Foster, Vivid Faces: The Revolutionary Generation in Ireland, 1890-1923 (London: Allen Lane, 2014), 289 and 328

i1 Collected Works of Pádraic H. Pearse, vol. 5: Political Writings and Speeches (Dublin, Cork and Belfast: The Phoenix Publishing Co., 1916), 133-7.

12 G. Beiner, "Between Trauma and Triumphalism: The Easter Rising, the Somme, and the Crux of Deep Memory in Modern Ireland', Journal of British Studies, 46, (2007), 366-89. 
of Transylvania, annexed by Romania. In response, irredentist monuments were erected in the truncated Kingdom of Hungary, planting an embittered memorial legacy which would return to haunt Central European politics. ${ }^{13}$ After the partition of Ireland, nationalist commemoration was banned in Northern Ireland while Orange celebrations of the twelfth of July, considered intolerable to the minority Catholic population, were adopted as state holidays. In southern Ireland, a purge of the markings of loyalist heritage resulted in the destruction of 'Big Houses' and the removal of imperial monuments. ${ }^{14}$ The forcefulness of this memorial iconoclasm, a phenomenon that can be labelled 'de-commemoration', was tempered by ambivalence over how independence had been achieved.

Commemoration of the Irish Revolution was stifled by bitter contentions. ${ }^{15}$ Whereas in Northern Ireland remembrance of the Great War was accorded pride of place within authorised Unionist culture, the governments of independent Ireland (who claimed to be the heirs of the rebels of 1916) were far less keen to commemorate the tens of thousands of Irishmen who had enlisted in the British army with the encouragement of the Irish Parliamentary Party. ${ }^{16}$ The disapprobation shown towards southern veterans, who wished to commemorate the Great War, was mirrored by the alienation of northern nationalists from Remembrance Day commemorations, which were conducted in Northern Ireland purely as Unionist events. ${ }^{17}$ Commemorative paralysis was

13 G. Beiner, " "No, Nay, Never" (Once More): The Resurrection of Hungarian Irredentism', History Ireland, 21, (2013), 40-4.

$14 \mathrm{~J}$. S. Donnelly, Jr, 'Big House Burnings in County Cork During the Irish Revolution, 1920-21', Eire-Ireland, 47, (2012), 141-97; T. Dooley, 'The Destruction of the Country House in Ireland, 1879-1973', in J. Raven (ed.), Lost Mansions: Essays on the Destruction of the Country House (Basingstoke and New York: Palgrave Macmillan, 2015), 44-62; Y. Whelan, "The Construction and Destruction of a Colonial Landscape: Monuments to British Monarchs in Dublin before and after Independence', Journal of Historical Geography, 28, (2002), 508-33.

15 D. Fitzpatrick, 'Commemoration in the Irish Free State: A Chronicle of Embarrassment' in McBride (ed.), History and Memory, 184-203.

$16 \mathrm{~K}$. Jeffery, Ireland and the Great War (Cambridge University Press, 2000), 107-43; N. C Johnson, Ireland, the Great War, and the Geography of Remembrance (Cambridge University Press, 2003); C. Switzer, Unionists and Great War Commemoration in the North of Ireland 1914-1939 (Dublin: Irish Academic Press, 2007), esp. 106-20; J. Turpin, 'Monumental Commemoration of the Fallen in Ireland, North and South, 1920-60', New Hibernia Review, 11, (2007), 107-19.

17 J. Leonard, 'Facing "the Finger of Scorn": Veterans' Memories of Ireland and the Great War', in M. Evans and K. Lunn (eds.), War and Memory in the Twentieth Century (Oxford and New York: Berg, 1997), 59-72; 'T. Canavan, 'The Poppy My Father Wore: The Problems Facing Irish Nationalists in Commemorating the Two World Wars', in E. Bort Commemorating Ireland: History, Politics, Culture (Dublin: Irish Academic Press, 2004), 56-67. particularly noticeable with regard to the Civil War, which had shaped the political fault lines of Irish politics and remained too controversial to be properly remembered in public. ${ }^{18}$ Struggles over ownership of nationalist traditions were apparent in the alternative memorial ceremonies held at Theobald Wolfe Tone's grave in Bodenstown, as well as at numerous local sites of memory, each of which contested official commemoration by the state. ${ }^{19}$

Memoirs of the War of Independence were bestsellers in the early years of the state and their authors, such as Dan Breen, Tom Barry and Ernie O'Malley, became celebrities. ${ }^{20} \mathrm{~A}$ great number of reminiscences of those who had participated in the struggle for Irish independence were compiled by government officials behind closed doors. In accordance with the Army Pensions Acts (1923 and 1953) and the Military Service Pensions Acts (1924, 1934 and 1949), applicants for state pensions were required to give their personal testimonies to the Department of Defence. Realising the historical value of such recollections, a specially designated Bureau of Military History collected between 1947 and 1957 a total of 1,773 witness statements and supplementary materials from veterans of separatist military organisations. These accounts, which reflect how the events were recollected after three decades, touched on sensitive issues. They were therefore kept out of the public eye and only released in the early twenty-first century. ${ }^{21}$

Folk memory was considered less controversial. However, concerns were raised about the survival of Ireland's rich oral traditions. Transformations in rural social practices brought a decline in the custom of evening gatherings in céilí (visiting) houses, which were described by American anthropologists in the 1930s as 'the seat of traditional lore and entertainment'. ${ }^{22}$ The sense that tradition was doomed to pass away served as a catalyst for the collecting of folklore and for developments in its study. The founding of the Folklore of Ireland Society in 1927 was followed by the establishment of an

18 A. Dolan, Commemorating the Irish Civil War: History and Memory, 1923-2000 (Cambridge University Press, 2003).

19 A. Dolan, An Army of Our Fenian Dead: Republicanism, Monuments and Commemoration', in F. McGarry (ed.), Republicanism in Modern Ireland (Dublin: UCD Press, 2003), 132-44.

20 D. Breen, My Fight for Irish Freedom (Dublin: Talbot Press, 1924); E. O'Malley, On Another Man's Wound (London: Rich \& Cowan, 1936); T. Barry, Guerilla Days in Ireland (Dublin: Irish Press, 1949).

21 The Bureau of Military History Collection was publicly launched in 2003 and has since been made available online: www.bureauofmilitaryhistory.ie. The phased release of the Military Service Pensions Collection commenced in 2014: www.militaryarchives.ie/collections/online-collections/military-service-pensions-collection.

22 C. M. Arensberg and S. T. Kimball, Family and Community in Ireland, 3rd ed. (Ennis, County Clare: Clasp Press, 2001), 186 
Irish Folklore Institute (1930), which was replaced in 1935 by the Irish Folklore Commission. Under the directorship of James Hamilton Delargy [Séamus Ó Duilearga], specially trained folklore collectors were sent throughout the thirtytwo counties on the island to document oral traditions. They recorded and transcribed the repertoire of storytellers and singers of local renown, many of whom no longer had a ready audience. A preference was shown towards Irishspeaking rural areas and long narrative tales (scéalaithe) were generally favoured over shorter folk history accounts (seanchas). By the time the commission was disbanded in 1970, its collections included 1,746 volumes of manuscripts. ${ }^{23}$

In addition, a Schools' Folklore Scheme organised in $1937-1938$ by the Irish Folklore Commission, in collaboration with the Department of Education and the Irish National Teachers' Organisation, involved some 100,000 children from 5,000 primary schools in the twenty-six counties of the Irish Free State. Well over half a million manuscript pages were written by the participating pupils, who collected accounts of traditions in their local communities, often from older family members. The Schools' Scheme, which showed more willingness to record traditions in English, reached many areas that had not been covered by the official folklore collectors. ${ }^{24}$ The ambitious extent of folklore collecting in Ireland is comparable to the United States Federal Writers' Project, created in 1935 as part of the New Deal. During the Great Depression, historians, teachers, authors and librarians were employed by the Works Progress Administration (WPA) to write local ethnographic accounts and to take down life histories, including the reminiscences of former slaves. ${ }^{25}$ These two contemporary projects shared a democratic belief that memories of common people living in purportedly backward areas had intrinsic historical value and were well worth preserving as a cultural resource for a modern nation. It should also be acknowledged that folk memory, as expressed in traditional forms of storytelling and vernacular commemoration, never fully died away and re-adaptations of folk history continued to persist through the twentieth century. ${ }^{26}$

23 M. Briody, The Irish Folklore Commission 1935-1970: History, Ideology, Methodology (Helsinki: Finnish Literature Society, 2007)

24 Ibid, , 260-70.

25 See J. Hirsch, Portrait of America: A Cultural History of the Federal Writers' Project (Chapel Hill: University of North Carolina Press, 2003); David A. Taylor, Soul of a People: The WPA Writer's Project Uncovers Depression America (Hoboken, NJ: Wiley, 2009).

$26 \mathrm{H}$. Glassie, Passing the Time in Ballymenone: Culture and History of an Ulster Community

(Philadelphia: University of Pennsylvania Press, 1982); G. Beiner, "The Decline and Rebirth of "Folk Memory": Remembering "The Year of the French" in the Late Twentieth Century', Eire-Ireland, 38, (2003), 7-32; R. Cashman, Storytelling on the Northern Irish Border: Characters and Community (Bloomington: Indiana University Press, 2008), 233-56.
Segregated commemoration of the First World War would continue also in regards to commemoration of the Second World War. In Northern Ireland, Catholic war veterans were again excluded from the official narrative of war remembrance. The neglect for over half a century to honour the achievement of James 'Mick' Magennis, the only serviceman from Northern Ireland to be awarded a Victoria Cross in the war, is a telling example of how a Catholic war veteran from west Belfast did not fit into the dominant narratives of unionist or republican memory. ${ }^{27}$ The southern state was altogether unwilling to recognise the many thousands of volunteers who defied Ireland's policy of neutrality and joined the effort to defeat Nazi Germany (including some 5,000 members of the Irish Defence Forces, who were branded deserters). ${ }^{28}$ Meanwhile, state commemorations of the Easter Rising continued annually and reached a climax in 1966.

The golden jubilee of 1916 was marked with parades, pageants, renaming of streets and buildings, dedication of memorial sites - most notably the Garden of Remembrance in Dublin city centre and the museum exhibition at Kilmainham Gaol, commissioning of artworks, issue of commemorative stamps and the production of films. Television was introduced as a new media for remembrance in the eight-part drama series Insurrection, directed by Louis Lentin, which was broadcast twice on Teilefís Éireann and was enthusiastically received by viewers. Éamon de Valera, the 84-year-old president (who was re-elected for another term that year) was at the centre of the state ceremonies, as the last surviving commandant of the Rising. None the less, the official commemorative programme shied away from nostalgic romanticised pastoral visions of Ireland, associated with de Valera, in favour of applauding the economic development identified with the modernising policies of the then Taoiseach Seán Lemass (also a veteran of the Rising). The government was determined to overcome political rifts and to avoid any celebration of violence, going as far as banning the playing of rebel songs on Radio Éireann. However, a committee of oppositional Republicans, chaired by another veteran, Joseph Clarke, defiantly mounted an alternative commemorative programme. The wives and sisters of prominent 1916 rebels were particularly vocal in their criticism of the official celebrations. Outside of organised commemoration, the most spectacular event of the fiftieth anniversary was the blowing up by the IRA of Nelson's Pillar, which had stood directly opposite the GPO - the main site of the 1916 commemoration. This illegal act of

27 G. Woodward, Culture, Northern Ireland, and the Second World War (Oxford, 2015), 1-2. 28 R. Doherty, Irish Volunteers in the Second World War (Dublin: Four Courts Press, 2002). 
de-commemoration fulfilled the drive to obliterate remnants of earlier commemorative culture and symbolically brought violence back on to the centre stage..$^{29}$

In June 1966, the prime minister of Northern Ireland Terence O'Neill attended a Great War commemoration in France for the 36th (Ulster) Division, which had been heavily recruited from the original Ulster Volunteer Force. He was called back home upon receiving news of a sectarian murder committed by a newly-revived paramilitary Ulster Volunteer Force (UVF). That year, permission given to northern nationalists to commemorate the Easter Rising's fiftieth anniversary provoked a loyalist counter-demonstration headed by Rev. Ian Paisley, who was determined to re-assert Unionist control over remembrance in the public sphere. A few years later, Conor Cruise O'Brien argued that the commemorations of 1916 in 1966 triggered the militant revival of the IRA, which allegedly led to the uncontainable outburst of violence in $1969 .{ }^{30}$ Even though the attribution of the outbreak of the Northern Irish conflict primarily to republican rituals of remembrance was a polemical exaggeration, the government of the Republic of Ireland promptly put an end to the annual military parades. Commemorative embarrassment was evident over the next decades and was particularly noticeable in the absence of official events during the seventy-fifth anniversary of the Easter Rising in $1991 .^{31}$

Nationalists in Northern Ireland, which in 1972 was put under Direct Rule, found in remembrance a powerful medium to counter official narratives. With the popularisation of psychoanalytical discourse, memories of violence were intrinsically regarded as traumatic. When British paratroopers opened fire on a civil rights march in Derry on 30 January 1972, killing 13 people and injuring 14 (one of whom was to subsequently die of his wounds), the Catholic community at large underwent a collective trauma, which was soon politicised. Outrage was channelled into grassroots commemoration after the Widgery Tribunal accepted the government's denial of misconduct. Subversive remembrance of Bloody Sunday was ritualised in annual memorial parades and was expressed through a wide array of

29 R. Higgins, Transforming 1916: Meaning, Memory and the Fiftieth Anniversary of the Easter Rising (Cork: Cork University Press, 2012); M. McCarthy, Ireland's 1916 Rising: Explorations of History-Making, Commemoration of Heritage in Modern Times (Farnham and Burlington: Ashgate, 2012), 187-273; see also M. E. Daly and M. O'Callaghan (eds.), 1916 in 1966: Commemorating the Easter Rising (Dublin: Royal Irish Academy, 2007).

30 C. C. O'Brien, States of Ireland (London: Hutchinson, 1972), 150.

31 D. Kiberd, 'The Elephant of Revolution Forgetfulness', in M. Ní Dhonnchadha and T. Dorgan (eds.), Revising the Rising (Derry: Field Day, 1991), 1-20. cultural representations, including literature and drama, cinema, sculpture, murals and countless memorabilia. ${ }^{32}$

In the second half of the twentieth century, there was a noticeable shift in the dominant international paradigm of commemoration, which moved from celebration of victors to remembrance of victims. Adoption of the Holocaust as a cosmopolitan memory of human rights gave cultural trauma a privileged status that could yield political dividends. ${ }^{33}$ This development was not lost on northern nationalists. The republican prisoner protest against the withdrawal of Special Category Status for convicted paramilitary members, which culminated in the hunger strike of 1981, became a memorial landmark. The funeral of IRA hunger-striker Bobby Sands in 1981 was attended by 100,000 people and the ten prisoners who starved to death were remembered as martyrs in annual commemorations, memorials and several feature films. Their memory was carefully stage-managed by the leadership of the provisional republican movement as a source of political legitimisation (although the leadership has since been criticised in a number of memoirs) ${ }^{34}$

In an age of growing globalisation, Irish memory was inherently transnational. For most of the twentieth century, there was a continuous outflow of disillusioned emigrants who left Ireland in search of a better life abroad. Disregarding the actual conditions of unemployment and dearth that were left behind, Irish diaspora communities sustained romanticised images of the homeland, continuing patterns of nostalgia from the nineteenth century that were especially prevalent among Irish-Americans. ${ }^{35}$ The often sentimental ways in which the 'auld sod' was remembered abroad were communicated in letters home, which in turn influenced local memories. Globalisation

32 S. Dunn, 'Bloody Sunday and Its Commemoration Parades', in T. G. Fraser (ed.), The Irish Parading Tradition: Following the Drum (New York: St: Martin's Press, 2000), 129-41; P. Hayes and J. Campbell, Bloody Sunday: Trauma, Pain and Politics (London and Ann Arbor: Pluto Press, 2005); G. Dawson, Making Peace with the Past? Memory, Trauma and the Irish Troubles (Manchester: Manchester University Press, 2007), 87-205; T. Herron and J. Lynch, After Bloody Sunday: Ethics, Representation, Justice (Cork: Cork University Press, 2007); A. Blaney, 'Remembering Historical Trauma in Paul Greengrass's Bloody Sunday', History and Memory, 19, (2007), 113-38; B. Conway, Commemoration and Bloody Sunday: Pathways of Memory (Basingstoke and New York: Palgrave Macmillan, 2010).

33 See D. Levy and N. Sznaider, 'Memory Unbound: The Holocaust and the Formation of Cosmopolitan Memory', European Journal of Social Theory, 5, (2002), 87-106; D. Levy and N. Sznaider, "The Institutionalization of Cosmopolitan Morality: The Holocaust and Human Rights', Journal of Human Rights, 3, (2004), 143-57.

34 S. Hopkins, "The Chronicles of Long Kesh: Provisional Irish Republican Memoirs and the Contested Memory of the Hunger Strikes', Memory Studies, 7, (2014), 425-39.

35 J. P. Byrne, 'Cultural Memory, Identity, and Irish-American Nostalgia', in O. Frawley (ed.), Memory Ireland, vol. 2: Diaspora and Memory Practices (Syracuse: Syracuse University Press, 2012), 49-60. 
contributed to the reinvention of traditions in Ireland, as in the importation of Americanised Saint Patrick's Day celebrations. ${ }^{36} \mathrm{~A}$ developing Irish heritage industry, catering for tourists as well as for an internal market, assumed an increasingly dominant role in promoting commercialised national and local presentations of the past. ${ }^{37}$ Generically berated as 'theme parks' that blatantly distort factual history, commemorative heritage came to play a key role in representing memory, often serving as a gateway to more rigorous historical explorations..$^{38}$ The fascination of Irish cinema with the past has been even more influential in reaching large audiences and shaping popular historical consciousness. The most striking example is Neil Jordan's Michael Collins (1996), which sparked a heated public debate on the War of Independence and the Civil War. ${ }^{39}$

The century ended with a worldwide revival of obsessive preoccupation with memorialisation, which has been described as a 'memory boom of unprecedented proportions ${ }^{3}{ }^{40}$ Echoing the apprehensions of the previous fin de siecle, postmodern critics maintained that connections with the past were about to be irrevocably severed. As put by the French historian Pierre Nora, in introducing his seminal concept of lieux de mémoire, 'we speak so much of memory because there is so little of it left'. ${ }^{41}$ On this background, the 1990s in Ireland evolved into a commemorative decade, which centred

36 M. Cronin and D. Adair, The Wearing of the Green: A History of St. Patrick's Day (London and New York: Routledge, 2006), 210-23.

37 D. Brett, The Construction of Heritage (Cork: Cork University Press, 1996); N. C. Johnson, 'Framing the Past: Time, Space and the Politics of Heritage Tourism in Ireland', Political Geography, 18, (1999), 187-207; E. Zuelow, Making Ireland Irish: Tourism and National Identity since the Irish Civil War (Syracuse: Syracuse University Press, 2009), 136-77.

38 R. F. Foster, The Irish Story: Telling Tales and Making It Up in Ireland (London and New York: Allen Lane, 2001), 23-36. Cf. G. Beiner, 'Commemorative Heritage and the Dialectics of Memory', in M. McCarthy (ed.), Ireland's Heritages: Critical Perspectives on Memory and Identity (Aldershot and Burlington: Ashgate, 2005), 55-69.

39 R. Barton, Irish National Cinema (London and New York: Routledge, 2004), 130-56. For additional discussion of the role of history in the film Michael Collins, see L. Gibbons, 'Framing History: Neil Jordan's Michael Collins', History Ireland, 1, (Spring 1997), 47-51; B. Mcllroy, 'History without Borders: Neil Jordan's Michael Collins', in J. MacKillop (ed.), Contemporary Irish Cinema: From The Quiet Man to Dancing at Lughnasa (Syracuse: Syracuse University Press, 1999), 22-8; R. Merivirta, The Gun and Irish Politics: Examining National History in Neil Jordan's Michael Collins (Bern and New York: Peter Lang, 2009).

$40 \mathrm{~A}$. Huyssen, Twilight Memories: Marking Time in a Culture of Amnesia (New York: Routledge, 1995), 1-9. See also J. Winter, 'Notes on the Memory Boom: War, Remembrance, and the Uses of the Past' in Duncan Bell (ed.), Memory, Trauma and World Politics: Reflections on the Relationship between Past and Present (Basingstoke and New York: Palgrave Macmillan, 2006), 54-73; D. W. Blight, 'The Memory Boom: Why and Why Now?', in P. Boyer and J. V. Wertsch, Memory in Mind and Culture (Cambridge University Press, 2009), 238-51.

41 P. Nora, 'Between Memory and History: Les Lieux de Mémoire’, Representations, 26 (1989), $7-24$ (quotation at 7). For a sociological study of contemporary culture as an agent on the sesquicentenary of the Great Famine and the bicentenary of the 1798 Rebellion. Affluence as well as politics played key roles in the burgeoning of commemoration.

Public remembrance of the Famine had previously been observed largely through muted commemoration, which should not be mistaken for silence, as the catastrophe of the Great Hunger [An Gorta Mór], commonly referred to in folklore as An Drocshaol [the Bad Times], was always a significant point of reference within Irish culture. Perhaps, the most noteworthy project of the centennial was a questionnaire circulated in 1945 by the Irish Folklore Commission to its full-time and part-time collectors, through which thousands of pages were collected that demonstrated (alongside other relevant accounts in the previously mentioned folklore collections) how the Famine was remembered in oral traditions. ${ }^{42}$ In conditions of economic stagnation, few resources were available to fund commemoration in the 1940s. In contrast, the hundred-and-fiftieth anniversary, which benefitted from the prosperity of the Celtic Tiger, was characterised by its monumentality. Community initiatives, private fundraising and substantial government support (to the total of one million pounds, allocated over three years), facilitated across Ireland and the Irish diaspora the erection of Famine monuments, which exhibited a range of varying complexities and aesthetic qualities. ${ }^{43}$

for loss of memory see P. Connerton, How Modernity Forgets (Cambridge University Press, 2009).

42 R. McHugh, 'The Famine in Irish Oral Tradition', in R. D. Edwards and T. D. Williams (eds.), The Great Famine: Studies in Irish History 1845-52 (Dublin: Lilliput Press, 1994; orig. ed. 1957), 389-436; C. Póirtéir, Famine Echoes (Dublin: Gill \& Macmillan, 1995). For an historical method to analyse this material, which distinguishes between three levels of memory: global, popular and local, see N. Ó Ciosáin, 'Approaching a Folklore Archive: The Irish Folklore Commission and the Memory of the Great Famine', Folklore, 115, (2004), 222-32.

43 Ireland's Famine: Commemoration and Awareness (Dublin: Famine Commemoration Committee, Department of the Taoiseach, 1995), esp. 56-60; D. Mullan, A Glimmer of Light: An Overview of Great Hunger Commemorative Events in Ireland and Throughout of Light: An Overview of Great Hunger Commemorative Events in Ireland and Throughout 'Hunger and History: Monuments to the Great Irish Famine', Textual Practice, 16, (2002), 249-76; P. Gray, 'The Memory and Commemoration of the Great Irish Famine', in P. Gray and K. Oliver, The Memory of Catastrophe (Manchester: Manchester University Press, 2004) 46-64; M. E. Daly " "History à la Carte?": Historical Commemoration and Modern Ireland' in Bort (ed.), Commemorating Ireland, 34-55; J. Crowley, 'Constructing Famine Memory: The Role of Monuments', in N. Moore and Y. Whelan (eds.), Heritage, Memory and the Politics of Identity: New Perspectives on the Cultural Landscape (Aldershot and Burlington: Ashgate, 2007), 55-67; E. Mark-FitzGerald, Commemorating the Irish Famine: Memory and the Monument (Liverpool: Liverpool University Press, 2013), esp 57-95. For commemoration in the United States see M. C. Kelly, Ireland's Great Famine in Irish-American History: Enshrining a Fateful Memory (Lanham, MD: Rowman \& Littlefield, 2014), 151-93. 
Even though sesquicentennial commemorations of the Famine, which had continued in its enormity at least until 1850 , should rightly have continued into the end of the century, the specially formed interdepartmental Government Commemoration Committee (based in the Department of the Taoiseach) shifted its attention towards the end of 1997 to the next planned commemorative programme. The two-hundredth anniversary of the 1798 Rebellion was identified as a 'project of significant national importance' and accordingly the bicentenary was commemorated through a staggering volume of commemorative activities that amounted, according to official estimates, to over one thousand events. In light of the breakthrough in the Northern Ireland peace process, which resulted in the signing of the Good Friday Agreement in 1998, the government maintained that 'attention should shift from the military aspects of 1798 and be directed towards the principles of democracy and pluralism which the United Irishmen advocated'. ${ }^{44}$

Outside Dublin, a large concentration of commemorative programmes took place around County Wexford, a main arena of the rebellion, including the opening of a National 1798 Centre in Enniscorthy. Numerous events were also held in other counties across Ireland and in Irish communities abroad. The most remarkable aspect of the bicentenary was the series of successful commemorations organised in Northern Ireland, notably in counties Antrim and Down, where the United Irish rebels had been predominantly Presbyterian. The centenary in Ulster in 1898 had resulted in de-commemorative riots, in which Protestant loyalists attacked nationalist celebrations, but the new political climate in 1998 was conducive to more inclusive commemoration that crossed, at least to some extent, the sectarian divide. ${ }^{45}$ The extensive involvement of a number of historians in the commemorations aroused controversy, with critics arguing that so-called 'post-revisionist' historical interpretations downplayed the extent of sectarian violence and overlooked atrocities committed during the rebellion. In comparative perspective, the debate in Ireland was considerably less divisive than the 'historian's feud' that had raged in

44 For documentation on the government's involvement in the commemorations see Government's 1798 Commemoration Committee National Programme (Dublin: Department of the Taoiseach, 1998); statement by the Taoiseach, Dail Eireann Debates, vol. 493, 3 July 1998; the 1798 Commemoration Committee's mission statement (April, 1997) published in Freedom of Information Act, 1997: Guide to the Functions and Records of the Department of the Taoiseach - Sections 15 and 16 Reference Book (Dublin: Department of the Taoiseach, 1998), 25; 1798 Commemoration Office strategy statement in Strategy Statement for the Department of the Taoiseach for the Years 1998-2000 (Dublin: Department of the Taoiseach, 2001), 43-4.

45 P. Collins, Who Fears to Speak of '98? Commemoration and the Continuing Impact of the United Irishmen (Belfast: Ulster Historical Foundation, 2004), 84-154.
France during the bicentenary of the French Revolution and the accusations levelled at Irish 'commemorationist history' may have been overstated. ${ }^{46}$

The century closed with the bicentenary of the passing of the Act of Union, which marked a historical event of major significance but did not ignite too much public interest, even among Unionists. The bicentenary of Robert Emmet was recalled in 2003 with the issue of a number of new biographies of the pre-eminent heroic icon of modern Irish memory. ${ }^{47}$ Concurrently, Irish historical studies, and Irish studies in general, caught up, albeit after a characteristic delay, with the surge in the study of memory that was already prominent in other countries since the late-1980s. Critical engagement with memory contributed towards moving Irish historiography and academic discourse beyond the revisionist debate, which had by then run its course. ${ }^{48}$

The developments in Irish commemoration in the 1990s opened the way for redress of previous neglect. Back in 1967, the historian F. X. Martin observed that 'outside of the Six Counties [of Northern Ireland], it is difficult to find men and women who will acknowledge that they are children of the men who were serving during 1916 in the British Army, the R.I.C. [Royal Irish Constabulary], the D.M.P. [Dublin Metropolitan Police], and Redmond's Irish National Volunteers'. Martin denounced this 'Great Oblivion' as 'an example of national amnesia'. ${ }^{49}$ Three decades later, the dedication of the Island of Ireland Peace Park by the battlefield of Messines in Flanders, which was unveiled by the Irish president Mary McAleese in conjunction with Queen Elizabeth II and the Belgian King Albert II at a Remembrance Day ceremony on 11 November 1998, signalled a rediscovery of interest in the memory of Irish participation in the First World War. The laying of a wreath at the cenotaph

46 R. F Foster 'Remembering 1798' in McBride (ed ), Historyand Memory 67-94. T. Dunne, Rebellions: Memoir, Memory, and 1798 (Dublin: Lilliput Press, 2004), 130-48. Cf. G. Beiner, "Commemorating "Ninety-Eight", in 1998: A Reappraisal of History-Making in Contemporary Ireland' in T. Botherstone, A. Clark and K. Whelan (eds.), These Fissured Isles: Ireland, Scotland and British History, 1798-1848 (Edinburgh: John Donald Publishers, 2005), 221-41. For the French controversy see S. L. Kaplan, Farewell, Revolution, vol. 1: The Historians' Feud, France, 1789/1989 and vol. 2: Disputed Legacies, France, 1789/1989 (Ithaca and London: Cornell University Press, 1995).

47 G. Beiner, 'The Legendary Robert Emmet and His Bicentennial Biographers', The Irish Review, 32 (2004), 98-104.

48 The landmark publication that signalled new-found interest in memory was the out come of the conference of Irish historians in Britain, which was held during the bicentenary of 1798; see I. McBride (ed.), History and Memory in Modern Ireland (Cambridge University Press, 2001). Since then, there have been numerous publications in the field. For critical discussion of the state of the arts see G. Beiner, 'Probing the Boundaries of Irish Memory: From Postmemory to Prememory and Back', Irish Historical Studies, 39, (2014), 296-307.

49 F. X. Martin, '1916: Myth, Fact, and Mystery", Studia Hibernica, 7 (1967), 68. 
outside Belfast City Hall by the first Sinn Féin Lord Mayor of Belfast, Alex Maskey, on the anniversary of the Battle of the Somme in 2002, encouraged northern republicans to engage with what had previously been considered an exclusively Unionist memory.

The Irish National War Memorial Gardens in Islandbridge (on the outskirts of Dublin city centre) hosted on 1 July 2006 a state commemoration of the ninetieth anniversary of the Battle of the Somme, which was attended by President McAleese, the Taoiseach Bertie Ahern, as well as delegates from Northern Ireland. After years of neglect, this grandiose memorial site (which was designed by the illustrious architect of British Great War commemoration, Edward Lutyens, but upon completion in 1939 had not been treated to an official opening) was finally restored to its original role. The marked enthusiasm with which the RTÉ Radio 1 broadcasts of the 2008 Thomas Davis lecture series on Ireland and the Great War were received by the general public revealed the growing emergence of interest in what was now labelled as 'Our War'..$^{50}$

The new commemorative inclusiveness was epitomised in the historic visit of Queen Elizabeth II to Ireland in May 2011 (the first royal visit since independence). Over the course of the visit, wreath-laying ceremonies took place at the Irish National War Memorial Gardens, as well at the Garden of Remembrance on Parnell Square (dedicated to the memory of the 1916 Rising). In a further gesture of conciliation, the queen also visited the GAA stadium at Croke Park, where in 1920 Crown forces had opened fire on a Gaelic football match killing 14 civilians in what would be remembered by nationalists as the original Bloody Sunday. This visit heralded the countdown towards the 'Decade of Centenaries', which promised to air the memory of the Great War, to reappraise the Easter Rising, to confront silenced memories of the Civil War, and to recognise other hitherto neglected events, such as the Dublin Lock-out of 1913.

Despite the brimming self-confidence displayed in the commemorations of the 1990s and the energetic preparations for the centenary of 1916, Irish memory at the turn of the twentieth century is once again in desperate need of regeneration. A veneer of sophistication disguises the stark reality that the officially-sanctioned representations of memory displayed in the public

50 A. Rigney, 'Divided Pasts: A Premature Memorial and the Dynamics of Collective Remembrance', Memory Studies, 1, (2008), 89-97; J. Horne (ed.), Our War: Ireland and the Great War (Dublin: Royal Irish Academy, 2008); K. Jeffery, 'Irish Varieties of Great War Commemoration', in J. Horne and E. Madigan, Towards Commemoration: Ireland in War and Revolution, 1912-1923 (Dublin: Royal Irish Academy, 2013), 117-25. sphere tend to feature a very narrow share of the diversity of historical experiences. Women are mostly excluded from the memorial meta-narratives, as are a wide range of alternative memories that pertain to ethnic, gender and class identities that do not conform to a perceived hegemonic mainstream. Irish social remembrance faces the imperative of coming to terms with glaring omissions that have long been repressed in public, but were often remembered in private. Under further exploration, it transpires that the history of Irish memory is riddled with social forgetting.

The uncovering of how the Irish government during the 1930s and the 'Emergency' had been unwilling to permit entry to Jewish refugees seeking to escape Nazi persecution, was regarded in 1998 as a historical precedent from which a moral lesson could be learned for the absorption of asylum seekers. It follows that the exclusion of minorities, not least the indigenous minority of Travellers, from national memory, begs redress. ${ }^{51}$ Many other such lieux d'oubli (to re-adapt Nora's term) await acknowledgement. There are no monuments or memorial sites for the deadly influenza epidemic of 1918-1919, which had an impact that exceeded that of the much-commemorated AngloIrish War. ${ }^{52}$ Likewise, recollections of the tuberculosis that afflicted countless families in Ireland are remembered in private, but have not yet entered public memory. ${ }^{53}$ Notwithstanding the secularisation and liberalisation of Irish society, memories of homosexuality have yet to become part of the mostly heterosexual, if not asexual, Irish story. ${ }^{54}$ These are but a few glaring examples of lacunae. Above all, the shocking revelations of institutional and clerical abuse have compelled Irish culture to grapple with finding means to ethically recall painful memories that defy sentimental remembrance of the recent past. ${ }^{55}$

51 Deogh, Jews in Twentieth-Century Ireland: Refugees, Anti-Semitism and the Holocaus (Cork: Cork University Press, 1998); K. Goldstone, ," Now You See Us, Now You Don 't": Reflections on Jews, Historical Amnesia and the Histories of a Multi-Ethnic Dublin', Translocations: Migration and Social Change, 4, (2008), 102-9; M. Ó hAodha, 'Reconfiguring the Traveller Self: Cultural Memory and Belonging', in Frawley (ed.), Memory Ireland, 185-96.

52 C. Foley, The Last Irish Plague: The Great Flu Epidemic in Ireland (Dublin: Irish Academic Press, 2011), 137-52; I. Milne, "Through the Eyes of a Child: "Spanish" Influenza Remembered by Survivors', in A. Mac Lellan and A. Mauger, Growing Pains: Childhood Illiess in Ireland, 1750-1950 (Dublin: Irish Academic Press, 2013), 159-74.

53 G. Simon, 'Cure Superstition, Infection and Reaction: Tuberculosis in Ireland, 19321957', Oral History, 32, (2004), 63-72; S. Kelly, 'Stigma and Silence: Oral Histories of Tuberculosis', Oral History, 39, (2011), 65-76.

54 D. Cregan, 'Remembering to Forget: Queer Memory and the New Ireland', in Frawley (ed.), Memory Ireland, 184-94.

55 E. Pine, The Politics of Irish Memory: Performing Remembrance in ContemporaryIrish Culture (Basingstoke: Palgrave Macmillan, 2011), 18-51; J. M. Smith, Ireland's Magdalen Laundries 
Northern Ireland, in its somewhat deceptively labelled 'post-conflict' state, is rife with unsettled memories. During the Troubles the divided communities cultivated their own sites of communal memory and often showed hostility towards rival commemorations. Terrorist attacks could assume a decommemorative purpose. The bombing of a Remembrance Day ceremony at Enniskillen on 8 November 1987 by the Provisional IRA, which left 11 dead and 63 injured, was a deliberate assault on what was considered a distinctly Unionist ritual of commemoration. ${ }^{56}$ Similarly, the attack on 16 March 1988 on the funeral of the 'Gibraltar Three' (a team of Provisional IRA volunteers, who had been killed by the SAS) at the republican plot in Belfast's Milltown cemetery by the loyalist gunman Michael Stone, who killed three of the mourners and injured another 50, violated a hallowed ritual of nationalist remembrance. ${ }^{57}$ The principle of 'parity of esteem' laid down by the Good Friday Agreement bestowed recognition on two rival traditions of incompatible historical memory, without finding effective ways to put them in constructive dialogue with each other. The murals on the walls of separate Catholic and Protestant neighbourhoods in Northern Ireland continue to display images of conflicting memories..$^{58}$ Moreover, Orange parades, celebrated annually in the July marching season repeatedly show potential to inflame sectarian conflict, as in the Drumcree standoffs in Portadown in the late 1990 s, which deteriorated into riots. ${ }^{59}$

Many families in Northern Ireland retain unbearably painful memories of loss and grief. ${ }^{60}$ Reflections of trauma have found cultural expressions in literature and in the performing and visual arts. ${ }^{61}$ The state authorities, however,

and the Nation's Architecture of Containment (Notre Dame, IN: University of Notre Dame Press, 2007).

56 D. McDaniel, Enniskillen: The Remembrance Sunday Bombing (Dublin: Wolfhound Press, 1997); H. Robinson, 'Remembering War in the Midst of Conflict: First World War Commemorations in the Northern Irish Troubles', Twentieth Century British History, 21, (2010), 80-101.

57 J. Smyth, 'Milltown Cemetery and the Politics of Remembrance', in J. Smyth, (ed.) Remembering the Troubles: Commemorating Constructing and Contesting the Recent Past in Northern Ireland (Notre Dame, IN: University of Notre Dame Press, 2017), 165-78.

$58 \mathrm{M}$. Forker and J. McCormick, 'Walls of History: The Use of Mythomoteurs in Northern Ireland Murals', Irish Studies Review, 17, (2009), 423-65; B. Rolston, "Trying to Reach the Future through the Past": Murals and Memory in Northern Ireland', Crime, Media, Culture, 6, (2010), 285-307.

59 D. Bryan, Orange Parades: The Politics of Ritual, Tradition, and Control (London and Sterling, VA: Pluto Press, 2000).

60 D. McKittrick, Lost Lives: The Stories of the Men, Women, and Children Who Died as a Result of the Northern Ireland Troubles (Edinburgh: Mainstream, 1999); S. McKay, Bear in Mind These Dead (London: Faber and Faber, 2008).

61 F. Barber, 'At Art's Edge: Post-Conflict Memory and Art Practice in Northern Ireland' in Frawley (ed.), Memory Ireland vol. 3, 232-46; S. Lehner, 'The Irreversible and have encountered difficulties in coming up with an acceptable policy for 'dealing with the past' and have been unable to institute inclusive commemoration of the victims of the Troubles. Models of 'truth and reconciliation' that were implemented in post-Apartheid South Africa and in Latin America have been deemed unsuitable, with Unionists, in particular, complaining that their social memory is not being adequately accommodated. It is quite possible that conflicts over memory of the Troubles will continue for a long time, as in Spain, where the memory of the Civil War of 1936-1939 remains an irreconcilable bone of contention in current political debate. ${ }^{62}$

There are clearly many significant recollections that have yet to be incorporated into public constructions of Irish memory. The promise of progress lies not so much with the authorities, whose ability to coordinate remembrance has proved to be limited and has always been contested, but more with the innovative memory work undertaken by individuals and community groups. Contemporary literature, theatre and film, as well as television and radio documentaries, are dealing creatively and working through some of these issues and have been facilitating meaningful interactions with memories of events that had hitherto been overlooked in public debate. New-found interest in oral history and the ongoing digitalisation of archival collections are producing resources for deeper understandings of the past and are stimulating the development of new methods for the study of memory. These initiatives are set to instigate an overhaul of Irish social and cultural memory, which will inevitably necessitate the rewriting of the history of the turbulent twentieth century.
Irrevocable: Encircling Trauma in Contemporary Northern Irish Literature', in ibid., 272-92.

62 B. Hamber (ed.), Past Imperfect: Dealing with the Past in Northern Ireland and Societies in Transition (Derry/Londonderry: INCORE, 1998); B. Graham and Y. Whelan, 'The Legacies of the Dead: Commemorating the Troubles in Northern Ireland', Environment and Planning D: Society and Space, 25, (2007), 476-95; M. B. Smyth, Truth Recovery and Justice after Conflict: Managing Violent Pasts (Oxford and New York: Routledge, 2007); K. Simpson, Unionist Voices and the Politics of Remembering the Past in Northern Ireland (Houndmills and New York: Palgrave Macmillan, 2009); K. Simpson, Truth Recovery in Northern Ireland: Critically Interpreting the Past (Manchester: Manchester University Press, 2009). 
THE CAMBRIDGE HISTORY OF

THE CAMBRIDGE HISTORY OF

I R E L A N D

GENBRAL EDITOR

THOMAS BARTLETT, professor emeritus of Irish history,

University of Aberdeen

This authoritative, accessible and engaging four-volume history vividly presents the Irish story - or stories - from c.600 to the present, within its broader Atlantic, European, imperial and global contexts. While the volumes benefit from a strong political narrative framework, they are distinctive also in including essays that address the full range of social, economic, religious, linguistic, military, cultural, artistic and gender history, and in challenging traditional chronological boundaries in a manner that offers new perspectives and insights. Each volume examines Ireland's development within a distinct period, and offers a complete and rounded picture of Irish life, while remaining sensitive to the unique Irish experience. Bringing together an international team of experts, this landmark history both reflects recent developments in the field and sets the agenda for future study.

VOLUMES IN THE SBRIES

VOLUME I

$600-1550$

EDITED BY BRENDAN SMITH

VOLUME II

$1550-1730$

EDITED BY JANE OHLMEYER

VOLUME III

$1730-1880$

EDITED BY JAMES KELLY

VOLUME IV

1880 to the Present

EDITED BY THOMAS BARTLETT

\section{IRELAND}

VOLUME IV

\section{0 to the Present}

\author{
Edited by
}

THOMAS BARTLETT

University of Aberdeen 